\title{
Motivational Factors that Influence English as a Foreign Language Learners at Quality Leadership University, Panama City, Panama
}

\author{
Ricardo Roman Jr. \\ Quality Leadership University, Panama City, Panama \\ Aixa M. Nunez \\ Quality Leadership University, Panama City, Panama
}

\begin{abstract}
Research in second language acquisition took off in the early 1970s. This study on integrative and instrumental motivation examined the correlation between the two forms in terms of second language acquisition, and the interest it has generated through continued research efforts in language learning. Research to date suggests a possible relationship between motivation and second language learning. The results obtained by this research were determined by two basic types of motivation which play a relevant role in second language acquisition, it also revealed which was the most prevalent motivational factor that influences students in learning English as a Foreign Language (EFL) at Quality Leadership University, Panama. Our objective was to prove that instrumental motivation is more prevalent among students learning English as a Foreign Language in Panama. Although cultural awareness is very much present in the EFL classroom, it too plays a major role with English Language Learners (ELLs). This is a quantitative research study which includes a questionnaire classifying twenty motivational statements into two types of motivation, integrative and instrumental. The study revealed that instrumental motivation was more prevalent among English language learners at Quality Leadership University, Panama. Albiet learning about new cultures has been the driving force with which students approach language learning and students in Panama are not the exception. We can thus conclude that instrumental motivation has been acknowledged as the significant factor by students surveyed and the interest in specific language learning for career advancement, whereas integrative motivation is linked to more general second language acquisition for the benefit of cultural integration.
\end{abstract}

Index Terms - instrumental motivation, integrative motivation, Second Language (L2), English as a Second Language (ESL), English as a Foreign Language (EFL), English Language Learners (ELL)

\section{INTRODUCTION}

According to Dörnyei (1998), the framework of Second Language (L2) learning motivation and Gardner's educational model posits learner level and learner situation levels. In the 1990s, the arguments about the validity of Gardner and Lambert's (1959) claim that integrative motivation is more facilitative for L2 acquisition in an English as a Foreign Language (EFL) classroom environment than that of instrumental motivation. Motivation could be best defined as a process that initiates, guides, and maintains goal-oriented behavior. This is true in the business world, and could also apply in an EFL setting. We will provide an overview of what motivates students in learning English. The hope is to provide a brief guide to the most common types of motivation involved in the learning of English under an EFL setting in Panama. Upon referring to the most prevalent scholars in the field of linguistics, and taking their input into consideration, we have determined that additional research is required to validate the true motivational factors that influence EFL students in Panama. Some argue that the theory on motivation to learn a Second Language (L2) requires a positive attitude towards the L2 community and a desire to become a member of that community (Gardner and Lambert, 1959). We will entertain this theory in our summary, considering the prospect that EFL learners in Panama feel the same way as other English as a Second Language (ESL) learners in the United States and abroad.

The main purpose of this research was to determine what motivates EFL learners in Panama to learn English, and what kind of motivation (integrative or instrumental) prevails among EFL students in Panama. We have made an unbiased attempt to answer the following questions:

1. What motivates EFL learners in Panama to learn English?

2. What kind of motivation (integrative or instrumental) prevails among EFL students in Panama?

This research focuses its attention to one prime factor, motivation. Motivation is a significant factor when it comes to doing anything, let alone the role in learning English as a foreign language. Humans are motivated by different things at different times throughout their lives. We can all relate to motivation, which relates to a person's intrinsic goals and desires. Students learning a foreign language know their preferences, limitations, strengths and weaknesses. It can be 
said that there is some correlation between intrinsic and extrinsic versus instrumental and integrative motivation. They possess cognitive and social theories of motivation respectively. Successful language learning is directly linked to the passion from within. Our intent was to focus on integrative and instrumental motivation and how it impacts foreign language learners. This research will make a significant contribution to the practice of teaching and learning English as a foreign language by setting a president on what really motivates EFL learners in Panama, and how to best address student motivation and future teaching methodologies. A thorough understanding of this topic should allow us to identify the integrative and instrumental factors in learning English.

We have justified this research based the concern as to what role integrative and instrumental motivational factors play in learning English and which competences in terms of language learning are most effective. Our intent was to help resolve the issue of why students are motivated more in either of the integrative or instrumental capacities. Students who are highly motivated achieve greater success than students who are not as motivated. For example, learning a second language in the United States of America, or English as a Second Language is critical for participating in a global community. English language learners in this area are more inclined to learn English under integrative motivation. We are facing a growing need to learn other languages at an unprecedented pace.

The United States promotes and strengthens the language skills of immigrants and their children and builds on second language mastery among non-native English speakers. The same can be said about learning English in Panama, albeit in an EFL setting. Motivation is defined differently according to its' different perspectives. We all draw different conclusions when it comes to motivation and in line with the behaviorist theory on motivation, it rewards those whom acquire positive reinforcement. In cognitive terms of behavior, it draws on the conclusions as to what types of motivation, integrative or instrumental students react to. We will shed some light on which one will be most beneficial for the student as well as for the facilitator providing instruction. In conducting this research, we hope to benefit not only the students, but the teachers as well. The results have enabled us to help diversify teaching methodology and incorporate new teaching strategies that will improve the students learning of English as a foreign language.

\section{LITERATURE REVIEW}

Over the years, motivation has been the focal point on what and how people do things. There is an old saying that goes "You can lead a horse to water, but you cannot make it drink it". In that sense, human beings also possess that chip in where they choose to do or not do things with enthusiasm. So it can be said that motivation holds no boundaries, and is not reminiscent to any particular social standing. The main motivator in this scenario is usually monetary and or promotion, which also work as motivators in the business field. Regardless of the cognitive rewards through extrinsic and intrinsic motivation, or social rewards through integrative and instrumental motivation. Students, like employees, never fail to recognize the importance of both and always strive to benefit from it. Along the same lines, motivation in education is not alone, its respective parts also work as with incentives. Students must be motivated to learn just as quickly; otherwise the learning process may not reach fruition. We all acquire language in much the same way. We would be remiss if we did not mention one of the leading experts in the field of linguistics. Dr. Noam Chomsky is one of the most influential linguists-social activists of the twentieth century. Through his insights, he highlights the Innateness Hypothesis as the main theory underlying first language acquisition. He is most famous for his unique linguistic theory on the Language Acquisition Device (Barman, 2012).

In terms of motivation, for many it comes naturally more so than for others. Ryan and Deci (2000) pp.69, argue that motivation is often treated as a singular construct, and even a shallow reproduction of this phenomenon proposes that people are moved to act differently depending on the types of factors which can be diverse experiences and consequences. This study will submit to these conclusions as well. We firmly believe that people and students are as equally motivated for various reasons under integrative and instrumental factors.

By conducting this research study, we anticipated that instrumental motivation was more prevalent among the EFL learners in Panama. Although we were certain that the participants would reflect to some degree both instrumental and integrative motivation, we also believed that we would find that instrumental motivation would be the major driver among the majority of the EFL learners in Panama. Our intent, therefore, is to prove that the tendencies of EFL learners in Panama would lean more towards instrumental motivation in nature as opposed to integrative motivation. This study seeks to answer some fundamental questions as to what kind of motivation do EFL students in Panama have regarding motivation and which is most prevalent (integrative or instrumental). Gardner and Lambert (1959) founded the premise of motivation and argue that integrative and instrumental motivation are the main factors, in which the first is defined as the learning a second language for the interest of learning more about the target language's culture and more in line with social interaction with the same, basically wanting to integrate into the target language. Whereas, instrumental motivation is more in line with students wanting to expand their careers or professional enterprise by improving their English prose. By incorporating instrumental motivational factors students may do just that, which differs from students learning a second language in the U.S.A., in where most may emphasize on integrative motivational factors to develop language skills seeking acceptance into a new culture.

In the field of education, motivation has been widely discussed by teachers, and scholars reference the workings that impact the success or failure of learning a second or foreign language. Without a doubt, both instrumental and integrative motivations are fundamentals of success in this learning process. Several studies on the relationship between 
learning and student motivation have been carried out by different researchers, and have all drawn on similar conclusions which reflect its' positive results.

It is under these conditions that we established our hypothesis that instrumental motivation is predominant amongst EFL students in Panama. English as a Second Language (ESL) is more prevalent in countries like the United States of America, among others. The premise however, is that students in an English as a Foreign Language (EFL) setting tend to learn English better through integrative motivational lesson plans. We believe this is important to note that given the conclusions by Gardner and Lambert (1959) on learning a second language or (L2) in this case, and considering instrumental or integrative motivation as a primary factor, we cannot shy away from the premise of learning a second language that is directly tied to motivation. How and why students learn a second language relies solely on their own motivations of course, with the guidance of an EFL/ESL instructor. The premise that ESL students learn English better under integrative motivational tendencies may be true in certain settings, which is not the issue here. The argument of which is most effective in Panama is the question we will entertain.

Which motivational factor is more predominant? There are more studies to be done in this field of motivational research. There is "food for thought" here for researchers to focus their theoretical insight, and more methodologists interested in classroom implications and applications based on results of future motivational research studies, all of which will open the door to improved EFL learning Dörnyei (1998).

Research studies on motivation in Second Language Acquisition (SLA) have been conducted by Dörnyei (2012). Traditionally, the focus of many motivational studies has been on describing motivational patterns of English language learners and finding a relationship between motivation and other variables in learning English as a foreign language. A major discovery made throughout this research was that the majority of studies analyzed the motivational component factors of integrative and instrumental tendencies in the United States as well as other countries. However, very few studies have been made in Latina America, or Panama, concerning this type of research. The intent of this research is to explore the motivational tendencies that Panamanian students have while they are learning English under the title of English as a Foreign Language.

The study seeks to answer some fundamental questions about what kind of motivation do EFL students have in Panama and what type of motivation is most prevalent (integrative or instrumental) among students in Panama? Instrumental is defined as learning the language in order to achieve some practical skills and objectives that are more indicative with the orientation or progress of the work that someone is undertaking, or career advancement. Research on motivation in SLA has led to the identification of potential similarities in terms of research questions, contexts, and research frameworks. This theme is not isolated; several studies have been done which have yielded varied results. Ahmadi (2011, p.12), stipulates that male students learning English in Iran have more tendencies towards the instrumental factor, and women have tendencies of the integrative factors. Several studies have been conducted on motivation. Dörnyei (2012) focuses on motivation to describe the motivational patterns of English learners.

It is important to note that there is an important theoretical shift that has recently been transforming the landscape of motivational research: the shift from the traditional conceptualization of motivation in terms of an integrative/instrumental dichotomy (Dörnyei, 2010). Motivation provides the primary impetus to initiate learning (L2) and the driving force to sustain the long and often tedious learning process; in fact, all other factors involved in the acquisition of L2 presuppose motivation to some extent Dörnyei (1998, p.117). Gardner and Lambert (1959) also indicated that in some cases and in certain settings, many people seem to dominate an L2, regardless of their differences in aptitude. Dörnyei (1998, p. 131), presented an overview of the different aspects and studies of motivation. Its main conclusion from this general view is that the motivation is actually multifaceted rather than a uniform factor and no available theory has managed to represent it in its total complexity. Dörnyei suggests that researchers should be very careful in developing and determining motivational variables in their studies. They need to be aware that specific motivational measures or concepts are being focused on higher-level segments related to motivation. As Williams (1994) briefly states: "there is no place for simplistic approaches to such complex issues as motivation".

Our research is based on a study conducted by Shahid Abrar-Ul-Hassan (2014, pp. 42-44) on the analysis of motivation types and degrees to reveal learners' expectations and learning objectives. His study classified a total of 14 statements into two types of motivation (intrinsic and extrinsic) and the degrees of motivation were identified as low, medium, or high. In conclusion, the study revealed students presented both types of motivational constructs and their motivation degree was at a medium level at the time the study was conducted.

Gardner and Tremblay (1994, pp.10) define L2 motivation as " the extent to which an individual works or strives to learn the language because of the desire to do so and the satisfaction experienced in this activity." The first language refers to the mother tongue that an individual learns; also, it is known as the main language or L1. Second language or (L2) target language refers to any language learned after the mother tongue or first language (L1).

According to Webster (2020) motivation is defined as:

1. The act or an instance of motivating, or providing with a reason to act in a certain way.

2. The state or condition of being motivated or having a strong reason to act or accomplish something.

Motivational factors can be categorized as cognitive and social terms respectively:

1. Intrinsic Motivation - The individual learns language without any outside incentive. 
2. Extrinsic Motivation - The individual learns a language because he believes that participation will result in promising results, such as rewards.

3. Instrumental Motivation - The individual learns a language with a more practical purpose, such achieving a higher social status, or moving up the business ladder.

4. Integrative Motivation - The individual learns a language because of positive ways to target language group and wishes to integrate into the target language.

Although intrinsic and extrinsic motivations have cognitive paradigms, they are closely related to integrative and instrumental motivation. Ryan and Deci (2000, p. 69) suggests that Cognitive Evaluation Theory (CET) specifies the factors in social contexts that produce variability in intrinsic motivation. CET, which is considered a sub-theory of selfdetermination theory, argues that interpersonal events and structures (e.g., rewards, communications, feedback) that conduce toward feelings of competence during action can enhance intrinsic motivation for that action because they allow satisfaction of the basic psychological need for competence. This is no doubt tied directly to integrative and instrumental motivation paradigms. Both draw on similar conclusions of competence towards a specific goal, in this case it is learning a second language. Although intrinsic and extrinsic motivations are not being considered in this study, we feel that they are directly linked to integrative and instrumental motivation.

\section{METHODOLOGY}

The expectation is to provide the most common stages of integrative and instrumental motivation involved in learning English as a foreign language and to develop viable research to complement the study. Taking into account their contribution, we have determined that much more research is required to validate the true motivational factors that influence EFL students in Panama. What kind of motivation do EFL students have in Panama? It is obvious that the level of motivation to want to learn a foreign language in Panama is important. Some students are motivated to varying degrees. We intend to analyze the results on integrative and instrumental motivation, and which is most prevalent for EFL learners in Panama. The hypothesis for this study is that instrumental motivation is prevalent among EFL learners in Panama. The key variables we have selected are instrumental and integrative motivation for learning English. Second language learners with instrumental motivation learn a language for reasons such as wanting to apply for college, obtain a better paid job or achieve a higher social status. On the other hand, learners with integrative motivation study a second language because they want to learn about the culture associated with that language. In most cases, they may want to integrate into the target language community.

The participants responded with genuine interest toward both instrumental and integrative motivation. The findings revealed that instrumental motivation was a major driver among the majority of the EFL learners in Panama. Our intent, therefore, was to prove that the tendencies of EFL learners in Panama would lean more towards instrumental motivation in nature as opposed to integrative motivation. Laying claim to the notion that most EFL students in this region hope to expand their careers by improving their English prose.

The study is quantitative, descriptive and non-experimental. Our research is mainly based on the study by Shahid Abrar-UL-Hassan (2014, pp. 42-44), A Study of the Motivational Patterns of Learners of English for Academic and Professional Purposes. We have adapted his study and have addressed twenty statements of which ten statements are related to instrumental motivation and ten statements are related to integrative motivation, respectively. The primary focus of motivation that was studied illustrated instrumental and integrative motivation tendencies. The instrument for data collection was a self report questionnaire consisting of two sections through the use of the Survey Monkey Application (Appendix A). The questionnaire consisted of two sections, of which participants were asked to respond to a series of statements related to their motivation. Section I solicits demographic information such as age, gender, nationality and income, etc. Section II was more specific, it was comprised of 20 statements identifying the two types of motivation factors involving (instrumental and integrative motivation formats).

The first ten statements (Items 1-10) focused on instrumental motivational tendencies and the next ten statements (Items 11-20) were related to integrative motivational tendencies. A 5-point Likert type rating scale was used in Section II where the rating ranged from 1 being Strongly Disagree and 5 being Strongly Agree. The participants were allowed five to ten minutes to fill out the questionnaire. The questionnaire was anonymous in order to maintain the confidentiality of responses made. The researchers personally administered the questionnaire in the classrooms after a brief introduction on the purpose of the survey.

A reliability analysis was conducted to measure the reliability of this study. A Cronbach's alpha analysis was employed to determine the internal consistency or average correlation of items in a survey instrument and to gauge its reliability. The results confirm that the instrument is highly reliable and falls within an acceptable value range as depicted on Table 1. We surveyed a sample size of 30 students to attain the results. Only twenty-six were valid at a $86.7 \%$ and four were excluded at $13.3 \%$. 
TABLE 1.

\begin{tabular}{|lll|}
\multicolumn{1}{l}{ TABLE 1. } \\
\begin{tabular}{|lll|} 
RELIABILITY ANALYSIS \\
Cases & $\mathrm{N}$ & $\%$ \\
Valid & 26 & $86.7 \%$ \\
Excluded & 4 & $13.3 \%$ \\
Total & 30 & $100.0 \%$ \\
\hline
\end{tabular}
\end{tabular}

Cronbach's alpha coefficient was implemented to test the proportion of observed variance with in the proposed survey. The alpha coefficient of .953 was sufficient enough to validate the survey implemented. The results are summarized in Table 2 .

TABLE 2.

CRONBACH'S ALPHA ANALYSIS

\begin{tabular}{|cc|}
\hline Reliability Statistics & \\
Cronbach's Alpha & N of elements \\
.953 & 20 \\
\hline
\end{tabular}

The population of 300 students was contemplated for this study, comprising of students enrolled in the English Program for Professional Development at Quality Leadership University (QLU) in Panama City, Panama. The sample for this investigation included 101 students, both male and female from QLU. This study was conducted during the month of January 2018 at the beginning of the first term. Table 3 reflects gender statistics, 66.3\% female participants versus $33.7 \%$ male. This is a reflection on how the EFL classroom female participation has increased.

TABLE 3.

\begin{tabular}{|lcc|}
\multicolumn{3}{|c}{ DEMOGRAPHIC INFORMATION } \\
\hline Gender & Response & Response \\
& Count & Percent \\
Male & 34 & $33.7 \%$ \\
Female & 67 & $66.3 \%$ \\
Total & 101 & $100.0 \%$ \\
\hline
\end{tabular}

Table 4 reflects the age groups of the participants in the survey. The ages were divided into seven groups. Group-1 (18-22 years) had 22 participants, Group- 2 (23-27 years) had 28, Group-3 (28-32 years) had 21, Group-4 (33-37 years) had 18, and Group-5 (38-42) had 9, Group-6 (43-47) had 2 and Group-7 (48-52) had 1. The results of the first three age groups account for $70.3 \%$ of the respondents. The majority of the respondents fell between 23 and 27 years of age, $27.7 \%$ of the total participants.

TABLE 4.

DEMOGRAPHIC INFORMATION (AGE)

\begin{tabular}{|ccc|}
\multicolumn{3}{c}{ DEMOGRAPHIC INFORMATION (AGE) } \\
\hline Age Groups & $\begin{array}{c}\text { Response } \\
\text { Count }\end{array}$ & Response Percent \\
$18-22$ & 22 & $21.8 \%$ \\
$23-27$ & 28 & $27.7 \%$ \\
$28-32$ & 21 & $20.8 \%$ \\
$33-37$ & 18 & $17.8 \%$ \\
$38-42$ & 9 & $8.9 \%$ \\
$43-47$ & 2 & $2.0 \%$ \\
$48-52$ & 1 & $1.0 \%$ \\
Total & 101 & $100.0 \%$ \\
\hline
\end{tabular}

It is also important to recognize that many of the respondents hold higher education level degrees. Those having a Bachelor's and Master's degree account for $80.2 \%$ of all respondents. Table 5 identifies the distribution of the educational level of the EFL population surveyed. A total of 57 or $56.4 \%$ of the respondents have a Bachelor's Degree, and a total of 24 respondents or $23.8 \%$ have a Master's Degree. Students know that by attaining a higher education level follows the same patterns of wanting to learn or improve their English as a Foreign Language for further career advancement.

TABLE 5.

DEMOGRAPHIC INFORMATION (EDUCATION)

\begin{tabular}{|lcc|}
\hline & Response & Response \\
& Count & Percent \\
High School & 14 & $13.9 \%$ \\
Technical School & 6 & $5.9 \%$ \\
Bachelor's Degree & 57 & $56.4 \%$ \\
Master's Degree & 24 & $23.8 \%$ \\
Total & \multicolumn{1}{c}{101} & $100.0 \%$ \\
\hline
\end{tabular}


Demographic information on nationalities captured in this survey was to depict international student participation. Table 6 reflects the cultural diversity we have in Panama. Results show that students from eight different countries, most of them are from Central and South America, were part of the research.

TABLE 6.

DEMOGRAPHIC INFORMATION (NATIONALITY)

\begin{tabular}{|llcc|}
\multicolumn{3}{c}{} & DEMOGRAPHIC INFORMATION (NATIONALITY) \\
\hline \multirow{5}{*}{ Valid } & & Response & Response \\
& & Count & Percent \\
& Other (Indicate) & 5 & $5.0 \%$ \\
& Panamanian & 72 & $71.3 \%$ \\
& Colombian & 5 & $5.0 \%$ \\
Lost & Venezuelan & 18 & $17.8 \%$ \\
Total & Total & 100 & $99.0 \%$ \\
& System & 1 & $1.0 \%$ \\
& & 101 & $100.0 \%$ \\
& & Response & Response \\
& & Count & Percent \\
& & 96 & $95.0 \%$ \\
& Brazilian & 1 & $1.0 \%$ \\
(Other) & Chinese & 1 & $1.0 \%$ \\
& Cuban & 1 & $1.0 \%$ \\
& Italian & 1 & $1.0 \%$ \\
& Paraguayan & 1 & $1.0 \%$ \\
& Total & 101 & $100.0 \%$ \\
\hline
\end{tabular}

The student population at QLU is formed by different income levels within the labor market. A student's culture and professional aspirations are directly tied to their motivation to want to learn English to improve their careers. Table 7 illustrates the income level of the students surveyed.

TABLE 7.

DEMOGRAPHIC INFORMATION (INCOME)

\begin{tabular}{|ll|c|c|}
\hline & $\begin{array}{c}\text { Response } \\
\text { Count }\end{array}$ & $\begin{array}{c}\text { Response } \\
\text { Percent }\end{array}$ \\
\hline \multirow{3}{*}{ Valid } & \$500 a \$800 & 21 & $20.8 \%$ \\
& \$801 a \$1000 & 15 & $14.9 \%$ \\
& \$1001 a \$1500 & 17 & $16.8 \%$ \\
& \$1501 a \$2000 & 17 & $16.8 \%$ \\
Lost & \$2000 o más & 23 & $22.8 \%$ \\
Total & Total & 93 & $92.1 \%$ \\
& System & 8 & $7.9 \%$ \\
& & 101 & $100.0 \%$ \\
\hline
\end{tabular}

\section{ANALYSIS AND DiSCUSSION}

The purpose of this analysis and discussion is to interpret and describe the significance of our findings. This study reports the findings based on a 5-point Likert Scale survey on instrumental and integrative motivation that was administered to students in the English for Professional Success (EPS) at QLU. The results proved that the majority of students had higher instrumental motivation (mean 4.2822), while the number of students with integrative motivation (mean 4.1756) was a slight lower. Table 8 below reflects the measurement results on instrumental motivation. The mean value of responses for each statement ranged between 3.45 and 4.69, (see statements 7 and 3 respectively). This is in direct combination with the 5-point Likert Scale, where 3 is (neutral) and 5 (strongly agree). Statement 3 "Better English proficiency will be useful in getting a good job" got the strongest agreement $(\mathrm{M}=4.6931, \mathrm{SD}=.717)$. In terms of agreement, statement (3) was followed by statement (6) and (1) ( $\mathrm{M}=4.6535$ and 4.5941, respectively, $\mathrm{SD}=.639$ and .763 respectively). The data clearly indicates that the participants' orientation is more towards instrumental motivation. However, statements (5) and (7) did not perform consistently with the rest of the items in the table. Statement 5 could be attributed to describing integrative motivational properties as discussed in earlier sections because world travel and learning about other cultures is directly related to integrative motivational objectives. 
TABLE 8.

INSTRUMENTAL MOTIVATION MEASUREMENT STATEMENTS

\begin{tabular}{|c|c|c|c|c|c|}
\hline Statement & $\mathbf{N}$ & Minimum & Maximum & Mean & SD \\
\hline $\begin{array}{l}\text { 1. I am learning English to improve } \\
\text { my reading and writing in English } \\
\text { for technical and professional } \\
\text { purposes. }\end{array}$ & 101 & 1.00 & 5.00 & 4.5941 & .76391 \\
\hline $\begin{array}{l}\text { 2. Learning English will enable me } \\
\text { to further my education. }\end{array}$ & 101 & 1.00 & 5.00 & 4.4257 & .87575 \\
\hline $\begin{array}{l}\text { 3. Better English proficiency will } \\
\text { be useful in getting a good job. }\end{array}$ & 101 & 1.00 & 5.00 & 4.6931 & .71753 \\
\hline $\begin{array}{l}\text { 4. Learning English will enable me } \\
\text { to keep up with development of } \\
\text { world economy, science and } \\
\text { technology (globalization). }\end{array}$ & 101 & 1.00 & 5.00 & 4.0891 & .98081 \\
\hline $\begin{array}{l}\text { 5. I am learning English because I } \\
\text { want to learn about various cultures } \\
\text { and people of the world. }\end{array}$ & 101 & 1.00 & 5.00 & 3.8317 & 1.07768 \\
\hline $\begin{array}{l}\text { 6. English will be helpful in my } \\
\text { professional growth and moving to } \\
\text { higher positions in my profession. }\end{array}$ & 101 & 1.00 & 5.00 & 4.6535 & .63931 \\
\hline $\begin{array}{l}\text { 7. I need the language in order to } \\
\text { take a test in the future. (E.g. TEFL, } \\
\text { TOIEC, TOEFL, etc.) }\end{array}$ & 101 & 1.00 & 5.00 & 3.4554 & 1.18764 \\
\hline $\begin{array}{l}\text { 8. English will enable me to seek } \\
\text { better job opportunities abroad. }\end{array}$ & 101 & 1.00 & 5.00 & 4.3564 & 91197 \\
\hline $\begin{array}{l}\text { 9. English will enable me to involve } \\
\text { or go into an international business. }\end{array}$ & 101 & 1.00 & 5.00 & 4.4851 & .78248 \\
\hline $\begin{array}{l}\text { 10. If I become a good speaker of } \\
\text { English, I can travel all over the } \\
\text { world. }\end{array}$ & 101 & 1.00 & 5.00 & 4.2376 & .87348 \\
\hline
\end{tabular}

Table 9 presents data results for the integrative motivation measurement statements. The mean value ranges between statements 17 and 20, M=3.8317 and 4.6832, SD=.9172 and .6622 respectively. Therefore, the data indicates that the participants also showed a level of integrative motivation. Statement 20, "The objective of learning English will help on trips abroad" received the strongest agreement, whereas Statement 17, "Learning English will enable me to understand better and appreciate more English art as well as literature" got the weakest agreement in the data.

TABLE 9.

INTEGRATIVE MOTIVATION MEASUREMENT STATEMENTS

\begin{tabular}{|l|c|c|c|c|c|}
\hline Statement & $\mathbf{N}$ & Minimum & Maximum & Mean & SD \\
\hline $\begin{array}{l}\text { 11. I would like to learn as many } \\
\text { languages as possible, and English is } \\
\text { one of them. }\end{array}$ & 101 & 1.00 & 5.00 & 3.9703 & .93226 \\
\hline $\begin{array}{l}\text { 12. I find English language learning } \\
\text { to be an exciting activity. }\end{array}$ & 101 & 1.00 & 5.00 & 4.0594 & .84643 \\
\hline $\begin{array}{l}\text { 13. Learning English will enable me } \\
\text { to understand the English life style } \\
\text { and culture. }\end{array}$ & 101 & 2.00 & 5.00 & 3.8416 & .88014 \\
\hline $\begin{array}{l}\text { 14. I learn English to be better } \\
\text { educated and feel confident. }\end{array}$ & 101 & 2.00 & 5.00 & 4.2178 & .90115 \\
\hline $\begin{array}{l}\text { 15. I think everybody should learn } \\
\text { English up to an intermediate } \\
\text { proficiency level. }\end{array}$ & 101 & 1.00 & 5.00 & 4.2871 & .85249 \\
\hline $\begin{array}{l}\text { 16. I believe that I have the right } \\
\text { attitude and am talented enough to be } \\
\text { highly proficient in English. }\end{array}$ & 101 & 1.00 & 5.00 & 4.4059 & .76391 \\
\hline $\begin{array}{l}\text { 17. Learning English will enable me } \\
\text { to understand better and appreciate } \\
\text { more English art as well as literature. }\end{array}$ & 101 & 1.00 & 5.00 & $\mathbf{3 . 8 3 1 7}$ & $\mathbf{. 9 1 7 2 7}$ \\
\hline $\begin{array}{l}\text { 18. I am interested in English movies } \\
\text { or songs. }\end{array}$ & 101 & 1.00 & 5.00 & 4.3700 & .84871 \\
\hline $\begin{array}{l}\text { 19. I would like to make friends with } \\
\text { people from other countries, } \\
\text { especially those from English- } \\
\text { speaking countries. }\end{array}$ & 101 & 1.00 & 5.00 & 4.0891 & $\mathbf{4 . 6 8 3 2}$ \\
\hline $\begin{array}{l}\text { 20. Learning English will help on } \\
\text { trips abroad. }\end{array}$ & 101 & 1.00 & $\mathbf{6 6 2 2 8}$ \\
\hline
\end{tabular}

Table 10 reflects the top ten rated responses related to Integrative and Instrumental motivation. Six of the ten responses were directly related to Instrumental Motivation, thus reflecting the majority interests of the students for 
wanting to learn English in Panama. We can observe that out of the top ten factors, $60 \%$ fell within the range of instrumental motivational factors (statements in bold) and $40 \%$ were related to integrative motivational factors.

TABLE 10.

TOP TEN MOTIVATIONAL FACTORS

\begin{tabular}{|l|c|c|c|c|c|}
\hline \multicolumn{1}{|c|}{ Statement } & $\mathbf{N}$ & Minimum & Maximum & Mean & SD \\
\hline $\begin{array}{l}\text { 3. Better English proficiency will be } \\
\text { useful in getting a good job. }\end{array}$ & $\mathbf{1 0 1}$ & $\mathbf{1 . 0 0}$ & $\mathbf{5 . 0 0}$ & $\mathbf{4 . 6 9 3 1}$ & $\mathbf{. 7 1 7 5 3}$ \\
\hline $\begin{array}{l}\text { 20. Learning English will help on trips } \\
\text { abroad. }\end{array}$ & 101 & 1.00 & 5.00 & 4.6832 & .66228 \\
\hline $\begin{array}{l}\text { 6. English will be helpful in my } \\
\text { professional growth and moving to } \\
\text { higher positions in my profession. }\end{array}$ & $\mathbf{1 0 1}$ & $\mathbf{1 . 0 0}$ & $\mathbf{5 . 0 0}$ & $\mathbf{4 . 6 5 3 5}$ & $\mathbf{. 6 3 9 3 1}$ \\
\hline $\begin{array}{l}\text { 1. I am learning English to improve my } \\
\text { reading and writing in English for } \\
\text { technical and professional purposes. }\end{array}$ & $\mathbf{1 0 1}$ & $\mathbf{1 . 0 0}$ & $\mathbf{5 . 0 0}$ & $\mathbf{4 . 5 9 4 1}$ & $\mathbf{. 7 6 3 9 1}$ \\
\hline $\begin{array}{l}\mathbf{9 . ~ E n g l i s h ~ w i l l ~ e n a b l e ~ m e ~ t o ~ i n v o l v e ~ o r ~} \\
\text { go into an international business. }\end{array}$ & $\mathbf{1 0 1}$ & $\mathbf{1 . 0 0}$ & $\mathbf{5 . 0 0}$ & $\mathbf{4 . 4 8 5 1}$ & $\mathbf{. 7 8 2 4 8}$ \\
\hline $\begin{array}{l}\text { 2. Learning English will enable me to } \\
\text { further my education. }\end{array}$ & $\mathbf{1 0 1}$ & $\mathbf{1 . 0 0}$ & $\mathbf{5 . 0 0}$ & $\mathbf{4 . 4 2 5 7}$ & $\mathbf{. 8 7 5 7 5}$ \\
\hline $\begin{array}{l}\text { 16. I believe that I have the right attitude } \\
\text { and am talented enough to be highly } \\
\text { proficient in English. }\end{array}$ & 101 & 1.00 & $\mathbf{5 . 0 0}$ & 4.4059 & .76391 \\
\hline $\begin{array}{l}\text { 18. I am interested in English movies or } \\
\text { songs. }\end{array}$ & 101 & 1.00 & $\mathbf{5 . 0 0}$ & 4.3700 & .84871 \\
\hline $\begin{array}{l}\text { 8. English will enable me to seek better } \\
\text { job opportunities abroad. }\end{array}$ & $\mathbf{1 0 1}$ & $\mathbf{1 . 0 0}$ & $\mathbf{5 . 0 0}$ & $\mathbf{4 . 3 5 6 4}$ & $\mathbf{. 9 1 1 9 7}$ \\
\hline $\begin{array}{l}\text { 15. I think everybody should learn } \\
\text { English up to an intermediate proficiency } \\
\text { level. }\end{array}$ & 101 & 1.00 & $\mathbf{5 . 0 0}$ & 4.2871 & .85249 \\
\hline
\end{tabular}

While entertaining the notion of what motivates EFL students in Panama, we drew on some conclusions early on regarding this hypothesis. Our intent was to prove that a higher number of the respondents surveyed would reveal that instrumental motivation was more prevalent among EFL learners in Panama. The results based on the survey provided some interesting data in that a little over half of the respondents were interested in improving their English skills for better job opportunities and career advancement (instrumental), while a slightly lower number showed an interest in the cultural aspect of learning the language (integrative).

From a pedagogical perspective, we have come a long way from Grammar Translation in teaching methods, albeit some of these facets are still being used today. Teachers must make every effort to motivate students. By designing up activities conducive to instrumental and integrative motivational factors simultaneously. Although the results favor instrumental learner biases, we cannot forget the integrative aspect of acquiring a second language, and the basis for its ease of learning. The challenge then is to persuade students accordingly and tap into what motivates each student specifically and design course content to reach that goal. These results are beneficial to both English course instructors and administrators. By identifying and understanding the different motivational patterns of EFL learners in Panama, educators will be in a better position to reengineer, redesign and enhance their lesson plans in the different English programs. Additionally, this type of information is important in prioritizing objectives in the different English programs.

The fact remains that the English language has become the world's most spoken language, mostly in terms of business. Several countries speak their own language and have made English their second language. Since globalization has adopted one single language for business, so there is a huge demand. Academic institutions and business organizations are looking to reinforce English language learning to succeed in education and in business. The Republic of Panama is among those countries which has adopted English as the official second language. Law No. 2 of January 14, 2003, Alvarado, (2003) mandates the provision of English as a second language throughout the country as per The Ministry of Education (Meduca). Article one (1) of sixteen (16) establishes that the English language is compulsory as the official language in the public and private educational centers at the elementary and high school grade levels, with the aim of contributing to the modernization of Panamanian education.

The study has unveiled what we had been hypothesizing. Students are primarily focused on instrumental motivation to acquire a new language, although integrative motivation also interests EFL student learning. The findings of this study on the influence of motivational factors on EFL learners demonstrated that specific motivation significantly determines the attitude to want to learn the language. The study reinforces the hypothesis that students want to learn English mainly for professional reasons. However, the fact remains that learners who identify with integrative motivational factors tend to assimilate English much faster than those inclined towards instrumental motivation (Gardner and Lamber, 1994). How well students learn or acquire English is not the question, but what motivates them to learn English is the question.

\section{Pitfalls}


The study was met with much optimism and anticipation. However, it was hampered by some limitations beginning with the small sample size of participants obtained due to time and travel constraints. The study focused on patterns of motivation of learners at only one institution providing English language programs in Panama City, thus the results were not generalizable to other programs or courses at other language institutions offered throughout the country.

Although the sample represented a small portion of the QLU population, it rendered positive results. The sample size of 101 students from the English for Professional Success (EPS) Program at QLU is only a small fraction of the whole population; therefore, the generalization from the findings should be made with forethought. Learners have different motivational attitudes toward different courses in an English program. Thus, patterns of motivation in the English programs surveyed and other programs or courses may not be the same. As Abrar-Ul-Hassan (2014) points out in his study, research on motivation faces this challenge, and our study is not an exception. The study, however, reiterates that a vast majority of the participants surveyed had both instrumental and integrative motivational characteristics. Additional research is needed to survey other learner population throughout the different provinces in Panama and different types of English program institutions. Also, we consider increasing the sample size to at least 300 or more for future research. Another limitation encountered was the time line, the time line given was two months. We undertook this study as participants in a research module program offered by QLU. We should, therefore, consider these results only as common and mutual finding of this investigation considering the time frame. The time to conduct the study was approximately two months to develop the survey, distribute, conduct and finalize it accordingly. Our hypothesis was based on the idea that EFL students' instrumental motivation could be higher than their integrative motivation.

\section{CONCLUSION}

The results of this study was to determine which of the two motivations, whether instrumental motivation or integrative motivation had greater influence on English as Foreign Language (EFL) learners in Panama. The results clearly indicate that EFL learners in Panama have a stronger instrumental motivation compared to integrative motivation. This was the basis of our investigation, to prove this hypothesis. The study revealed that EFL students learn English to fulfill academic and professional milestones (instrumental). There were students that showed interest in learning English for integrative motivational purposes; albeit in the slight minority of this study, they prove to be significant in the data results.

The results of this research coincide with the study from Shahid Abrar-ul-Hassan (2014) on Motivation in learning English as a second and foreign language of Iranian students. His research proved that instrumental motivation is more vital in learning a second language, especially the English language among Middle Eastern students. It is important to note that although instrumental motivation had been acknowledged as a significant factor among male students interested in specific language learning for career purposes. Integrative motivation was linked to general second language acquisition for the benefit of cultural awareness, females in his study were more attracted to this area. In this study, the majority of the EFL students in Panama realize the need for English language learning in their daily conversations with friends and family, and or in business. For them, English is primarily important and used as a principal tool for business and academic purposes. The study of instrumental and integrative motivation was interesting in that it pointed out that EFL students want to learn English for professional purposes, such as doing assignments, presentations, talking to lecturers or to score well on examinations. They feel that it is not as important for them to master the language for cultural or interpersonal relations, more so than it is for career advancement.

\section{RECOMMENDATIONS}

This research suggests that there is a significant relationship between the success of second language learning and the kind of motivation among EFL students in learning the second language in Panama and instrumental motivation had a greater influence towards this achievement. It is recommended that expanding the sample size in further studies will strengthen this type of research. This study will contribute to aid teachers of EFL in that they can modify their teaching styles to better facilitate student motivation and learning practices. Students interact with language activities that are relevant to integrative and instrumental motivation as long-term goals of professional and cultural awareness, directly related to the target language. Both integrative and instrumental motivations are essential elements of language learning success. Instrumental motivation has been found to sustain long-term success when learning English as a second language. It is recommended that additional research on instrumental and integrative motivation towards English language learning be conducted in the region. 
APPENDIX. QUESTIONNAIRE FOR EFL STUDENTS

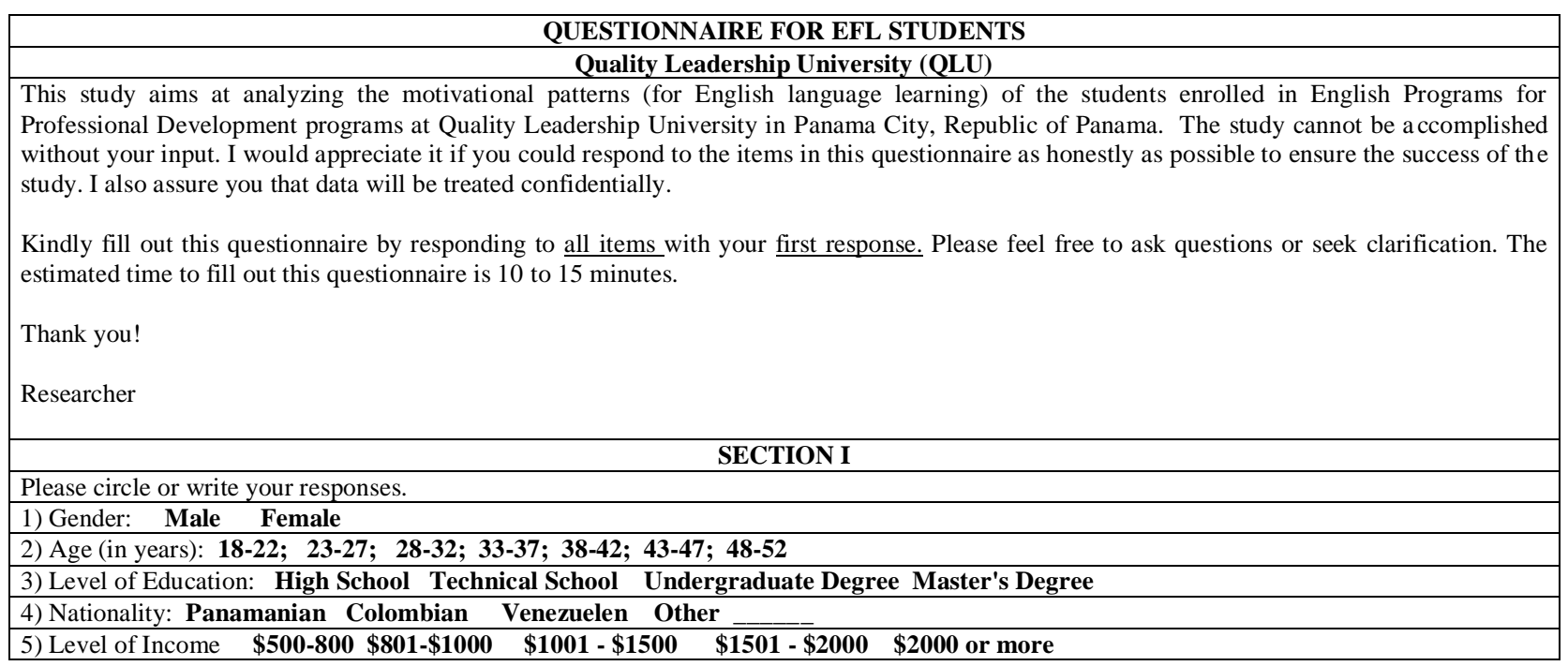

\section{SECTION II}

Read the following statements carefully and record your response to each statement on the given 5 -point scale. Please cirlce the number which most closely matches your opinion toward each statement, (ONE response only) (e.g., "Strongly Agree," "Agree," "Disagree," "Neutral," or "Strongly Disagree")

\begin{tabular}{|c|c|c|c|c|c|}
\hline & $\begin{array}{l}\text { Strongly } \\
\text { Disagree }\end{array}$ & Disagree & Neutral & Agree & Strongly Disagree \\
\hline $\begin{array}{l}\text { 1. I am learning English to improve my reading and } \\
\text { writing in English for technical and professional } \\
\text { purposes. }\end{array}$ & 1 & 2 & 3 & 4 & 5 \\
\hline $\begin{array}{l}\text { 2. Learning English will enable me to further } \\
\text { education. }\end{array}$ & 1 & 2 & 3 & 4 & 5 \\
\hline $\begin{array}{l}\text { 3. Better English proficiency will be useful in getting a } \\
\text { good job. }\end{array}$ & 1 & 2 & 3 & 4 & 5 \\
\hline $\begin{array}{l}\text { 4. Learning English will enable me to keep up with } \\
\text { development of world economy, science and } \\
\text { technology (globalization). }\end{array}$ & 1 & 2 & 3 & 4 & 5 \\
\hline $\begin{array}{l}\text { 5. I am learning English because I want to learn about } \\
\text { various cultures and people of the world. }\end{array}$ & 1 & 2 & 3 & 4 & 5 \\
\hline $\begin{array}{l}\text { 6. English will be helpful in my professional English } \\
\text { growth and moving into high positions in my } \\
\text { profession. }\end{array}$ & 1 & 2 & 3 & 4 & 5 \\
\hline $\begin{array}{l}\text { 7. I need the language in order to take a test in the } \\
\text { future. (E.g. TEFL, TOIEC, TOEFL, etc.) }\end{array}$ & 1 & 2 & 3 & 4 & 5 \\
\hline $\begin{array}{l}\text { 8. English will enable me to seek better job } \\
\text { opportunites abroad. }\end{array}$ & 1 & 2 & 3 & 4 & 5 \\
\hline $\begin{array}{l}\text { 9. English will enable me to involve or go into an } \\
\text { international business. }\end{array}$ & 1 & 2 & 3 & 4 & 5 \\
\hline $\begin{array}{l}\text { 10. If I become a good speaker of English, I can travel } \\
\text { all over the world. }\end{array}$ & 1 & 2 & 3 & 4 & 5 \\
\hline $\begin{array}{l}\text { 11. I would like to learn as many languages as possible, } \\
\text { and English is one of them. }\end{array}$ & 1 & 2 & 3 & 4 & 5 \\
\hline $\begin{array}{l}\text { 12. I find English language learning to be an exciting } \\
\text { activity. }\end{array}$ & 1 & 2 & 3 & 4 & 5 \\
\hline $\begin{array}{l}\text { 13. Learning English will enable me to understand the } \\
\text { English life style and culture. }\end{array}$ & 1 & 2 & 3 & 4 & 5 \\
\hline $\begin{array}{l}\text { 14. I learn English to be better educated and feel } \\
\text { confident. }\end{array}$ & 1 & 2 & 3 & 4 & 5 \\
\hline $\begin{array}{l}\text { 15. I think everybody should learn English up to an } \\
\text { intermediate proficiency level. }\end{array}$ & 1 & 2 & 3 & 4 & 5 \\
\hline $\begin{array}{l}\text { 16. I believe that I have the right attitude and am } \\
\text { talented enough to be highly proficient in English. }\end{array}$ & 1 & 2 & 3 & 4 & 5 \\
\hline $\begin{array}{l}\text { 17. Learning English will enable me to understand } \\
\text { better and appreciate more English art as well as } \\
\text { literature. }\end{array}$ & 1 & 2 & 3 & 4 & 5 \\
\hline 18. I am interested in English movies or songs. & 1 & 2 & 3 & 4 & 5 \\
\hline $\begin{array}{l}\text { 19. I would like to make friends with people from other } \\
\text { countries, especially those from English-speaking } \\
\text { countries. }\end{array}$ & 1 & 2 & 3 & 4 & 5 \\
\hline 20. Learning English will help on trips abroad. & 1 & 2 & 3 & 4 & 5 \\
\hline
\end{tabular}




\section{ACKNOWLEDGEMENTS}

The authors wish to thank Dr. Ricardo Acosta G., Honorary Dean, and Andrea Miranda (M.A.), Research and Accreditation Coordinator, from Quality Leadership University for their support in conducting this research.

\section{REFERENCES}

[1] Abrar-UL-Hassan, S. (2014). A Study of the Motivational Patterns of Learners of English for Academic and Professional Purposes. TESOL Journal 5.1, March 2014, Sultan Qaboos University, https://pdfslide.net/documents, pages, 42,43,44.

[2] Ahmadi, Mohammad Reza, (2011) The Effect of Integrative and Instrumental Motivation on Iranian EFL Learners' Language Learning. April 2011 ISSN: 2230-9136, ELT Voices, India, page 12 http://eltvoices.in/ Volume1/Issue2/EVI12_2.pdf.

[3] Alvarado, Carlos, Legislative Assembly Law No. 2 (2003) The Ministry of Education (Meduca) January 14, 2003 http://www.unachi.ac.pa/assets/descargas/vic_academica/2-de-2003-jan-16-2003.pdf

[4] Barman, Binoy, (2012). The Linguistic Philosophy of Noam Chomsky. Philosophy and Progress: Vols. LI-LII, January-June, July-December, 2012 ISSN 1607-2278 (Print), DOI : http://dx.doi.org/10.3329/pp.v51i1-2.17681.

[5] Cheng, H.F., \& Dörnyei, Z. (2007). The use of motivational strategies in language instruction: The case of EFL teaching in Taiwan. Innovation in Language Learning and Teaching, Vol. 1, No. 1, 2007.

[6] Deci, L. Edward., Ryan M. Richjard. (2014). University of Rochester, January 2000, American Psychologist. Contemporary Educational Psychology 25, 54-67 (2000), doi:10.1006/ceps.1999.1020, available online at http://www.idealibrary.com, pp.58.

[7] Dörnyei, Z. (1998). Motivation in second and foreign language learning. Language Teaching, 31, pp 117-135 doi:10.1017/S026144480001315X

[8] Dörnyei, Z. (2010). Researching motivation: from integrativeness to L2 self.I n S. Hudson and D. Oakley, (Eds) Introduction to Applied Lingusitics: (Concepts and Skill pp. 74-83)

[9] Dörnyei, Z. (2012). Motivation in second and foreign language learning Zoltan Dornyei Thames Valley University, London

[10] Gardner and Lambert. (1959). Fifty Years and Counting1 R. C. Gardner Department of Psychology University of Western Ontario

[11] Gardner and Tremblay. (1994). Department of Psychology. University qf Western Ontario. London, on Canada N6A 5C2. P. F. TREMBLAY. Department of The Modern Language.

[12] Ryan and Deci. (2000). Self Deternination Theory and the Facilitation of Intrinsic Intrinsic Motivation, Social Development, and, Well being. University of Rochester, January 2000 - American Psychologist, the American Psychological Association, Inc. Vol. 55, No. 1, 68-78, pg.69.

[13] Webster, Merriam. (2020). https://www.merriam-webster.com/dictionary/motivation.

[14] Williams, M. (1994). Motivation in foreign and second language learning: An interactive perspective. Educational and Child Psychology, 11(2), 77-84.

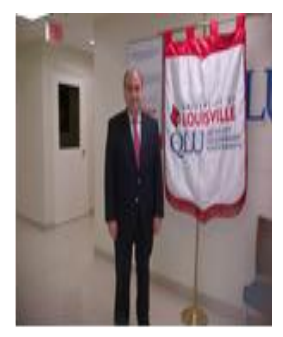

Ricardo Roman Jr. was born on November 4, 1958. He is originally from Chicago Illinois. He holds a Bachelor of Arts degree in Latin American and Caribbean Studies (LACS) from Florida State University (1998), a Master of Science Degree in Business Administration (MBA) from NOVA Southeastern University (2001), and a Master of Arts degree in Teaching English to Speakers of Other Languages (TESOL) from the College of Notre Dame of Maryland (2009).

$\mathrm{He}$ is a veteran of the U. S. Army having served for 16+ years as a Combat and Combat Heavy Engineer. As a Non-Commissioned Officer he served on numerous deployments to Central and South America, including South Korea. He has been teaching English and business courses for various universities in Panama, e.g. Latina University, International University of Panama, and Quality Leadership University, for the past 18 years. He has been residing in Panama since 1995 with his family. He is currently conducting action research on motivation factors that influence students in the Bachelor's degree program at QLU in Panama, as well as continued research in first and second language acquisition of EFL students in Panama.

Mr. Ricardo Roman Jr. also served on the U.S. American Society Board in Panama (1996-1998) where he served as a director. He also served as President of the U.S. Navy League Board in Panama (2001-2002). This is his first official research paper being submitted entitled Motivational Factors that Influence EFL Learners at Quality Leadership University, Panama City, Panama for the publication to the Journal of Language Teaching and Research.

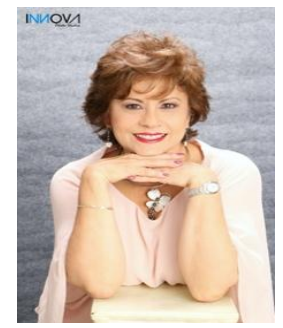

Aixa M. Núñez was born in the former Canal Zone, Republic of Panama on January 22, 1956. She grew up as an Air Force military dependent in the United States and later in the former Canal Zone, Republic of Panama. She obtained her Bachelor's Degree in Business Administration from the Florida State University, Panama Canal Branch (1978). She later received a Master of Arts in Teaching English to Students of Other Languages (TESOL) from the College of Notre Dame of Maryland (2009).

She worked as a civilian for the U.S. Army, based in Panama, for 25 years as a Manpower Management Analyst. She retired in 1999 from the U.S. Government and continued working as a Personnel Assistant and Secretary for the Panama Canal Authority for 13 years. She currently lives in Panama with her family. She has been teaching English to adult students in the English for Professional Development Program at Quality Leadership University (QLU) since 2004. Since 2017, she has been teaching Introduction and Intermediate College Writing courses in the Undergraduate Program at QLU. Furthermore, she has her own independent business in the area of Nutrition and Health and owns a Smoothie and Protein Bar. This is her first official research paper being submitted entitled Motivational Factors that Influence 
EFL Learners at Quality Leadership University, Panama City, Panama for the publication to the Journal of Language Teaching and Research.

Mrs. Aixa M. Núñez additionally obtained her license as an Authorized Official Translator/Interpreter in the languages of English/Spanish in 2015. She became a member of the Asociación Panameña de Traductores e Interpretes (APTI) in 2016. 